\title{
The Ulnar Nerve After Surgical Transposition: Can Sonography Define the Reason of Persisting Neuropathy?
}

\author{
Der Nervus ulnaris nach chirurgischer Transposition: Kann \\ die Sonografie die Ursache einer anhaltenden Neuropathie definieren?
}

Authors

Affiliations
H. Gruber ${ }^{1}$, E. M. Baur² ${ }^{2}$ M. Plaikner ${ }^{1}$, A. Loizides ${ }^{1}$

Department of Radiology, Innsbruck Medical University, Innsbruck, Austria

Department of Plastic-, Reconstructive- and Aesthetic Surgery, Innsbruck Medical University, Innsbruck, Austria

\author{
Key words \\ - elbow \\ - nervous-peripheral \\ - ultrasound
}

received 29.3.2015

accepted $\quad 11.5 .2015$

Bibliography

DOI http://dx.doi.org/

10.1055/s-0035-1553221

Published online: 19.6.2015

Fortschr Röntgenstr 2015; 187 :

998-1002 @ Georg Thieme

Verlag KG Stuttgart · New York .

ISSN 1438-9029

\section{Correspondence}

Dr. Alexander Loizides

Department of Radiology,

Innsbruck Medical University

Anichstraße 35

6020 Innsbruck

Austria

Tel.: +43/5 12/5 04/22761

Fax: $+43 / 512 / 504 / 22758$

alexander.loizides@i-med.ac.at

\section{Zusammenfassung}

$\nabla$

Ziel: Die Ulnarisneuropathie wird durch eine Einengung auf Höhe des Kubitaltunnels verursacht. Derzeit sind zwei chirurgische Hauptschulen für die Behandlung einer Ulnarisneuropathie bekannt: Dekompression des Nervens in seiner üblichen Lage oder Nerventransposition auf die ulnare Beugeseite. Diese Arbeit wurde durchgeführt, um den Nutzen der Sonografie bei Patienten mit persistierender Symptomatik nach Ulnaris-Transposition zu definieren.

Material und Methoden: Wir präsentieren die Daten von 8 Patienten mit persistierender Symptomatik nach Transposition der Nervi ulnares. Querschnittsflächen (CSA) sowie Texturänderungen wurden dokumentiert. Jeder Nerv wurde in 6 Segmente - 3 Segmente am proximalen Durchtritt und 3 Segmente am distalen Durchtritt durch die subkutane Faszie segmentiert.

Ergebnisse: Textur-Veränderungen konnten in $4,6(76,7 \%) \pm 1,2$ nachgewiesen werden, Veränderungen der äußeren Nervenscheide in 4,1 $(68,3 \%) \pm 1,1$ der Segmente. Kaliber-Veränderungen basierend auf die 6 Segmente konnten nachgewiesen werden: eine CSA von $7,45 \mathrm{~mm}^{2} \pm 2,24$ wurde proximal des oberen Faszien-Durchtritts (PUF) gefunden, am oberen Faszien-Durchtritt (UF) eine mittlere CSA von $11,96 \mathrm{~mm}^{2} \pm 3,61$, distal des oberen Faszien-Durchtritts (DUF) eine mittlere CSA von $11,49 \mathrm{~mm}^{2} \pm 8,16$, proximal des unteren Faszien-Durchtritts (PLF) eine mittlere CSA von $10,84 \mathrm{~mm}^{2} \pm 4,73$, am unteren Faszien-Durchtritt (LF) eine mittlere CSA von $12,12 \mathrm{~mm}^{2} \pm 5$ und distal des unteren Faszien-Durchtritts (DLF) eine mittlere CSA von $7,89 \mathrm{~mm}^{2} \pm 3,42$. Alle verlagerten Nerven zeigten relevanten Knickstellen an der UF, 6 Nerven präsentierten relevanten Knickstellen an der LF.

Schlussfolgerungen: Die Sonografie kann in Fällen von sekundärer Ulnarisneuropathie nach Transposition des Nervs zuverlässig die tatsäch-

\section{Abstract \\ $\nabla$}

Purpose: Ulnar nerve neuropathy is mainly caused by compression at the level of the cubital tunnel. Two main approaches are currently known for the surgical treatment of this condition: decompression of the nerve in its usual position or transposition to the ulnar flexor side. This study was performed to define the usefulness of ultrasound in patients with persisting symptoms after ulnar nerve transposition.

Materials and Methods: We present the data of 8 subjects with persisting symptoms after nerve transposition due to compressive neuropathy. The cross-section areas (CSA) and texture changes were recorded. Each ulnar nerve was divided into 6 segments -3 segments at the proximal pass and 3 segments at the distal pass through the subcutaneous fascia.

Results: Texture changes were recorded in 4.6 $(76.7 \%) \pm 1.2$ and outer nerve sheath blurring in mean $4.1(68.3 \%) \pm 1.1$ of the segments. Caliber changes were found in the course of the nerve based on the 6 segments: A mean CSA of $7.45 \mathrm{~mm}^{2} \pm 2.24$ was found proximal to the upper fascial passage (PUF), a mean CSA of $11.96 \mathrm{~mm}^{2} \pm 3.61$ at the upper fascial passage (UF), a mean CSA of $11.49 \mathrm{~mm}^{2} \pm 8.16$ distal to the upper fascial passage (DUF), a mean CSA of $10.84 \mathrm{~mm}^{2} \pm 4.73$ proximal to the lower fascial passage (PLF), a mean CSA of $12.12 \mathrm{~mm}^{2} \pm 5$ at the lower fascial passage (LF), and a mean CSA of $7.89 \mathrm{~mm}^{2} \pm 3.42$ distal to the lower fascial passage (DLF). All transposed nerves presented relevant kinks at the UF, 6 nerves presented relevant kinks at the LF.

Conclusion: In cases of secondary ulnar neuropathy after nerve transposition, ultrasound can reliably assess the actual "situation" of the nerve and thus at least ease the decision for secondary surgery. 
liche „Situation“ des Nervs beurteilen und somit die Entscheidung einer Sekundär-Operation erleichtern.

Kernaussagen

- Die Sonografie kann zuverlässig eine Pathologie des Nervus ulnaris definieren.

- Blutflussrestriktion nach Nerv-Transposition kann eine mögliche Ursache einer sekundären Neuropathie sein.

- Die Sonographie kann eine sekundäre Neuropathie nach Ulnaris-Transposition definieren.

\section{Introduction}

\section{$\nabla$}

Ulnar Nerve Neuropathy is dominantly based on compression at the level of the cubital tunnel [1] where the nerve suffers directly from mechanical forces and/or impairment of its vascular supply [2]. During the last decades two main surgical approaches have been developed and involve resolving the abovementioned problems by either loosening the nerve in its usual topographic position as in-situ decompression or transposing it - with or without fitting of the bony epicondyle - usually subcutaneously to the flexor side of the elbow [1,3-6]. However, concerning the surgical transposition of the ulnar nerve, early constriction of the intraneural blood flow by dislocating not only the nerve but also its blood supply and thus perfusion was feared [1, 4, 7-9]. Although in this context recommendations for surgical procedures are available [2], a first-line standard recommendation is not clearly defined, $[9,10]$ and potential sites of "vascular constriction" and how such a state could be diagnosed have not yet been defined. Within the last decade high-resolution ultrasonography (HRUS) has become the first-line modality for imaging small soft tissue structures and especially for imaging peripheral nerves: with high-frequency broadband transducers and highly sensitive color and power Doppler, even tiny peripheral nerve branches and arterial vessels can be visualized. Even subtle forms of peripheral nerve pathology may also be demonstrated by inner texture change [11 - 15]. However, can HRUS play a relevant role in admittedly rare patient collectives under suspicion of relevant secondary/iatrogenic blood flow compromise of a transposed ulnar nerve?

\section{Materials and Methods \\ $\nabla$}

We present the data of 8 subjects who had undergone standard subcutaneous transpositions of the ulnar nerves due to compressive neuropathy of the cubital nerve segments. Persistence or even aggravation of their clinical symptoms (specific palsy, numbness and pain) and - if available $(n=5)$ - at least lacked amelioration in electrophysiological tests (EDX) i.e. sensory nerve action potential at specific measurement (SNAP) and/or combined motor action potential (CMAP) were evident. We assessed these patients during the daily routine by our standard HRUS algorithm (which includes an axial scan loop over the whole cubital nerve segment of interest and corresponding longitudinal scans) using a $17-5 \mathrm{MHz}$ linear array transducer on a Philips IU22 ${ }^{\circledR}$ (Philips Ultrasound, Bothell, WA) and using a $10 \mathrm{~mm}$ stand-off pad for improvement of US coupling. All measurements were made by the Philips IU22 ${ }^{\circledR}$ caliper tool defining the axial cross-section measurements as described below. Institutional review board approval for the current investigation was
Key points

- Sonography can reliably define pathology of the ulnar nerve.

- Blood flow restriction after nerve transposition can be the cause of secondary neuropathy.

- Secondary neuropathy after ulnar nerve transposition can be assessed by sonography.

Citation Format:

- Gruber H., Baur E. M., Plaikner M. et al. The Ulnar Nerve After Surgical Transposition: Can Sonography Define the Reason of Persisting Neuropathy?. Fortschr Röntgenstr 2015; 187: 9981002

granted by means of a general waiver for investigations with retrospective analysis of data (Ethikkommission Innsbruck 274/ 19.02.2009). All data were handled according to the Austrian and European regulations concerning the protection of patient rights and sensitive patient-related data.

Between January 2011 and December 2014, the abovementioned 8 subjects (mean age 46.7 years, standard deviation 18.9) presented 8 surgically transposed ulnar nerves which were assessed and measured between 6 and 18 months after initial surgery. For the purpose of comparable evaluation, each transposed ulnar nerve was retrospectively divided into 6 segments -3 segments at the proximal pass and 3 segments at the distal pass through the subcutaneous fascia (proximal to, at the end distal to the respective entrance/exit through the subcutaneous fascia). At these 6 segments (proximal to upper fascial passage [PUF], upper fascial passage [UF], distal to upper fascial passage [DUF], proximal to lower fascial passage [PLF], lower fascial passage [LF], distal to lower fascial passage [DLF]) the cross-section areas of the transposed nerves were recorded and texture changes (loss of the inner fascicular texture and blurring of the outer nerve sheath) were assessed by two investigators in consensus, each with more than 8 years of experience in musculoskeletal and nerve sonography.

Additionally focal "kinks" of the transposed nerves at their transit through the fasciae were recorded. At the UF and LF, deviation of an ulnar nerve's course was classified as a kink if a deflection of the respective longitudinal axis at these points was obvious.

Repeat operation was indicated consensually by the "institutional peripheral neurology board" if substantial amelioration (clinical presentation, HRUS and EDX data) was expected. Patients who had longtime unchanged clinical and electrophysiologic nerve impairment were not expected to profit from any secondary surgery as chronic nerve damage leads to a "burn out" nerve which is a definite final situation.

Secondary surgery included mainly following measures:

1. Loosening of the constrictions at the respective nerves at their passes through the subcutaneous fasciae by amply opening these fasciae and

2. Fitting of the transposed nerve to a smooth and non-impaired, i.e. not angulated, course (which was proved intraoperatively by passive motion) through its extra-anatomic compartment. Due to the rather limited patient number, only descriptive statistics were deemed useful. All data storage and calculations were done in Microsoft Excel ${ }^{\circledR}$ (Seattle, WA, USA) including mean value definitions (with calculation of standard deviations) and all calculations necessary for box-plotting ( $1^{\text {st }}$ and $4^{\text {th }}$ quartile values, maximum and minimum values) for the cross-section areas and definition of mean values (with standard deviations) and median values for the segments of the transposed nerves with texture changes. 


\section{Results}

$\nabla$

All subjects who had undergone standard subcutaneous transposition of the ulnar nerve due to compressive neuropathy of the cubital segment of the ulnar nerve presented a "transposed" nerve to the ulnar flexor side at the cubita with preserved continuity. No neuroma or any sign of major nerve impairment or rupture was found. Beyond the respective entrances and exits through the subcutaneous fasciae, no compressions, e.g. by scars or bony elements, were obvious.



Fig. 1 Whisper boxplot of the transposed nerves concerning the integrated cross-section areas (CSAs) of the 6 measured segments: The range lines indicate the maxima and the minima of the respective segments (proximal to upper fascial passage [PUF], upper fascial passage [UF], distal to upper fascial passage [DUF], proximal to lower fascial passage [PLF], lower fascial passage [LF], distal to lower fascial passage [DLF]) with the corresponding boxes ranging between the 1st and the $3 \mathrm{rd}$ quartiles of the datasets with the corresponding midrange median values given within the boxes.

Abb. 1 Whisper boxplot der verlagerten Nerven hinsichtlich der integrierten Querschnittsfläche (CSA) der 6 gemessenen Segmente: Die Bereich-Linien zeigen die Maxima und Minima der jeweiligen Segmente (proximal des oberen Faszien-Durchtritts [PUF], am oberen Faszien-Durchtritt [UF], distal des oberen Faszien-Durchtritts [DUF], proximal des unteren Faszien-Durchtritts [PLF], am unteren Faszien-Durchtritt [LF], distal des unteren Faszien-Durchtritts [DLF]) mit den korrespondierenden Boxen zwischen den 1. und 3. Quartilen der Datensätze und den angegebenen Median-Werten.
However, the ulnar nerves presented texture and caliber changes at their transposed courses:

(ner texture changes were recorded in $4.6(76.7 \%) \pm 1.2(20 \%)$ (18.3\%) of the segments.

. Marked caliber changes were found in the course of the transposed nerve based on the 6 segments defined above. We found a mean cross-section area (CSA) of $7.45 \mathrm{~mm}^{2} \pm 2.24$ (median $6.05 \mathrm{~mm}^{2}$ ) proximal to the upper fascial passage (PUF), a mean cross-section area (CSA) of $11.96 \mathrm{~mm}^{2} \pm 3.61$ (median $\left.10.04 \mathrm{~mm}^{2}\right)$ at the upper fascial passage (UF), a mean cross-section area (CSA) of $11.49 \mathrm{~mm}^{2} \pm 8.16$ (median $9.83 \mathrm{~mm}^{2}$ ) distal to the upper fascial passage (DUF), a mean cross-section area (CSA) of $10.84 \mathrm{~mm}^{2} \pm 4.73$ (median $8.3 \mathrm{~mm}^{2}$ ) proximal to the lower fascial passage (PLF), a mean crosssection area (CSA) of $12.12 \mathrm{~mm}^{2} \pm 5$ (median $8.58 \mathrm{~mm}^{2}$ ) at the lower fascial passage (LF), and a mean crosssection area (CSA) of $7.89 \mathrm{~mm}^{2} \pm 3.42$ (median $5.11 \mathrm{~mm}^{2}$; see $\bullet$ Fig. 1) distal to lower fascial passage (DLF).

3. All transposed nerves presented relevant kinks at the UF, 6 nerves presented relevant kinks at the LF.

Of the abovementioned 8 subjects, 3 were (as described above) expected to clearly profit from surgery and thus underwent secondary surgical release also as described above by the institutional peripheral neurology board.

The assessments of the corresponding situses during surgery confirmed the US findings in detail. Inner texture changes were clearly beyond the scope as was blurring of the outer nerve sheath. The swelling of the corresponding segments of the ulnar nerve especially at the hourglass-shaped, waisted transits through the fascia and the kinks were recorded (॰ Fig. 2-4).

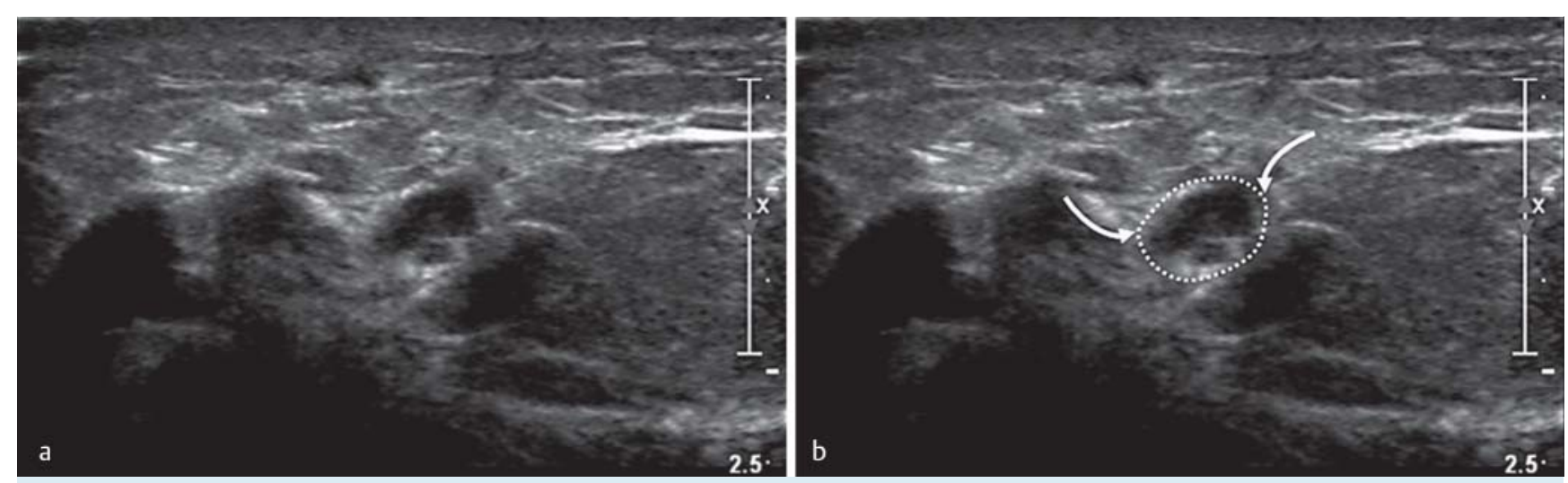

Fig. 2 a, b Axial ultrasound scan at the UF depicting the texture of the transposed ulnar nerve (dotted line) with hypoechoic changes at its passes through the distorted fascia (arrows).

Abb. 2 a, b Ultraschall B-Bild in einem Transversalschnitt an der UF mit Darstellung des hypoechogen veränderten, verlagerten Nervs (gepunktete Linie) an seinem Durchgang durch die Faszie (Pfeile). 

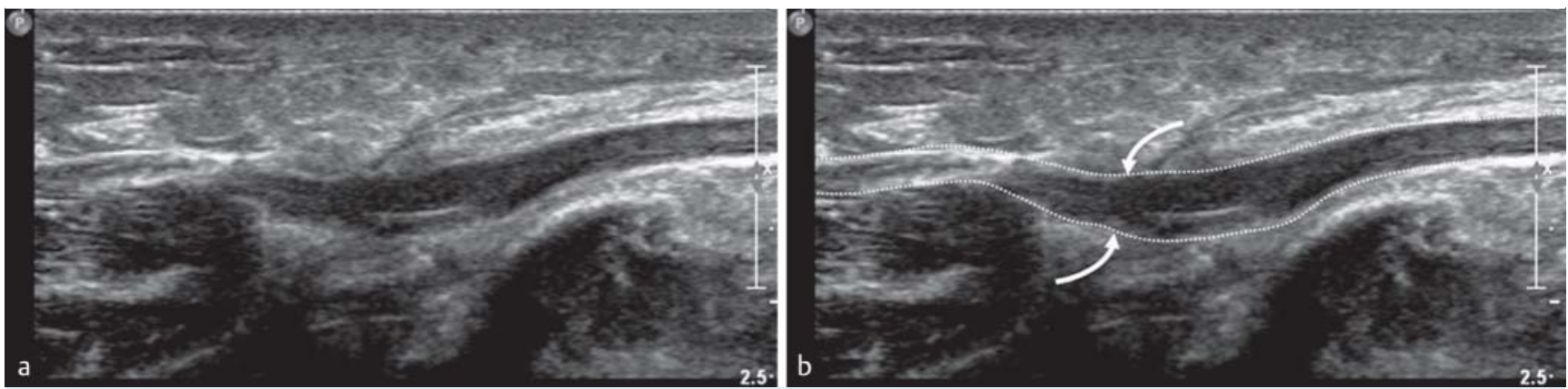

Fig. 3 a, b Longitudinal ultrasound scan depicting the fusiform swelling of the transposed ulnar nerve (dotted line) at its exit through the subcutaneous fascia (arrows).

Abb. 3 a, b Ultraschall B-Bild in einem Längsschnitt mit Darstellung der spindelförmigen Auftreibung des verlagerten Nervs (gepunktete Linie) am Austrittspunkt durch die subkutane Faszie (Pfeile).

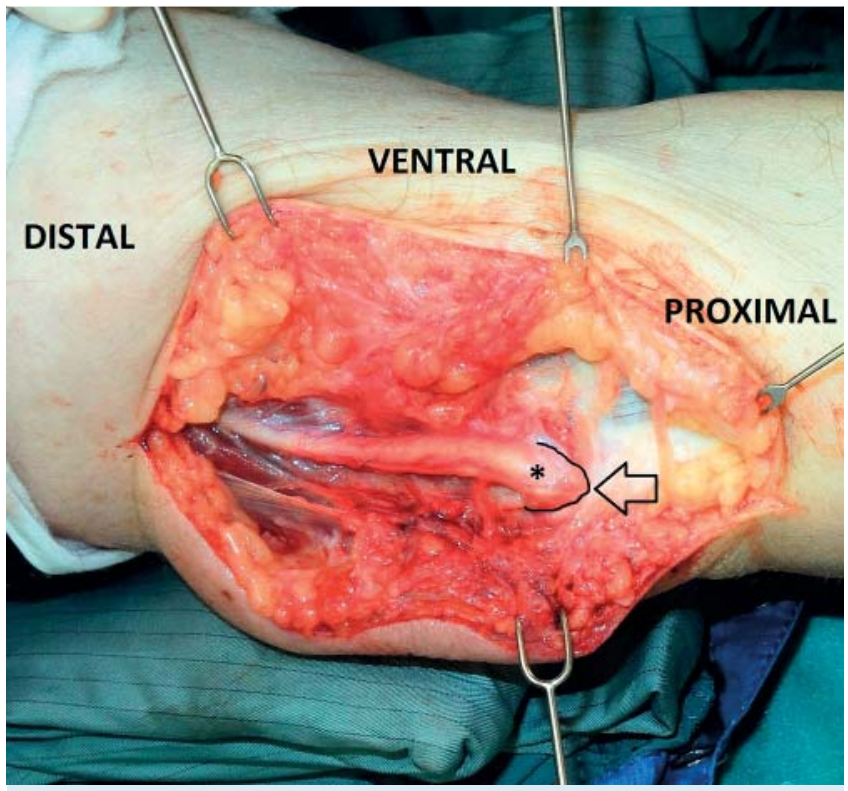

Fig. 4 The corresponding intraoperative situs shows the in vivo situation as described in $\bullet$ Fig. 2 the transposed ulnar nerve $\left({ }^{*}\right)$ exiting through the subcutaneous fascia of which the border is marked by a thin, black line. Also here the maximum caliber of the fusiform nerve is evident at the UF (arrow).

Abb.4 Der entsprechende intraoperative situs zeigt die in-vivo-Situation, wie in $\bullet \mathbf{A b b} .2$ beschrieben: der verlagerter Nerv $\left({ }^{*}\right)$ am Austrittspunkt durch die subkutane Faszie dessen Grenze durch eine dünne schwarze Linie markiert ist. Auch hier ist der maximale Kaliber des spindelförmig aufgetriebenen Nervs an der UF nachweisbar (Pfeil).

All 3 subjects who had undergone these secondary surgical revisions showed prompt and marked clinical ameliorations of the according sensory (pain, paresthesia and numbness) and motor qualities of the respective ulnar nerve within 3 months. No corresponding EDX controls are available.

\section{Discussion}

As defined by the available literature, transposition of the ulnar nerve - although performed charily - may profoundly hamper the nerve additionally instead of solving the problem of mechan- ical constriction of the cubital segment of an ulnar nerve. Several secondary reasons are under discussion, but "academic opinions" do not help these harried patients, who hoped for amelioration by "transposition surgery" and then suffered from substantially more pain than before.

However, transpositions of ulnar nerves are presently done rather rarely- due to the probability of "iatrogenic" harming of an ulnar nerve - and much more rarely end up in insufficient situations as described above, which urges for solutions. The surgeon wants to help but does not exactly know what to revise and the neurologist/electrophysiologist often has to delay further action due to unclear data. Since in such situations electrophysiological tests were actually pathologic at/in the cubital segment of an ulnar nerve and are still pathologic after initial surgery, pain is subjective and motor functions need time to recover.

However, the data of this retrospective study present some interesting facts that should at least be discussed:

1. US can depict unexpected constrictions and thus strangulation of a transposed nerve due to clear morphology. Kinks and caliber change is actually nothing new, but helps the clinician in assessing the situation and further prognosis also in this rather special but important field.

2. US can give information when interpretation of EDX data is unclear. Due to chronic neural damage, data lose relevance and thus do not suffice for decisions. US can rather clearly state a "need for action".

3. Our data based on the CSA measurements show additional facts. If there was exclusive constriction only to the axonal flow, the corresponding nerve should be swollen in a pseudoneuroma-like manner mainly proximal to the point of relevant constriction and show distal to that rather "normal" caliber as known from carpal tunnel syndrome $[16,17]$. This is (astonishingly!) not true for our patients at all! At the UF we find more swollen nerves with texture changes than at PUF and at least rather swollen nerves distal to that (i.e., the actually transposed ulnar nerve segment; DUF) - the situation at the LF is a little different but also here an expected CSA reduction is more or less lacking. How these facts should be explained in detail may not be clarified by this study, but there is clearly something beyond mere axonal/fascicular constriction which affects these caliber and texture changes! In our opinion the major candidate for this "something" should be a segmentally changed intraneural blood supply which was already claimed to be "changed" by such surgical procedures but without clear 
diagnostic evidence [18]. Hampered neural blood supply could also explain the severe neural function loss in morphologically unspectacular circumstances due to ischemia.

Based on our data, we propose to focus also on the diagnostic relevance of neural perfusion in - at least special forms of - compression neuropathy beyond direct neural impairment of peripheral nerves to preserve the best further prognosis for a concerned patient. In this context the field should e.g. be opened to contrast-enhanced ultrasound (CEUS), by which assessment of nerve segments under suspicion of "dysperfusion" should be eased and thus quickly define the need for further action.

In this spirit our present study - using admittedly a very confined, retrospective dataset - could demonstrate the use of HRUS for cases of special forms of secondary (highly hampering) neural compromise. HRUS can define "what is going on" and "where" and thus state what the surgeon should do if also all other circumstances "favor" intervention, i. e. at least substantial amelioration is expected. Further data on the constriction of perfusion of a peripheral nerve might here become as crucial as it may play a key role for therapeutic options in the future. However, our data (CSA, texture changes) additionally ask questions we can presently not clearly answer but blaze a trail on how "blood flow management" changed prognosis. Different forms of nerve constriction may play different roles and in this sense further data should be provided.

\section{Clinical relevance}

1. Ultrasound can define constrictions and caliber changes of the ulnar nerve after subcutaneous transposition.

2. Ultrasound can provide information and state the need for action when interpretation of EDX data is unclear.

3. Ultrasound should be the first-line imaging modality in patients with persisting neuropathy after ulnar nerve transposition.

\section{References}

1 Palmer BA, Hughes TB. Cubital tunnel syndrome. J Hand Surg Am 2010; 35: 153 - 163 PubMed PMID: 20117320. Epub 2010/02/02. eng.

2 Messina A, Messina JC. Transposition of the ulnar nerve and its vascular bundle for the entrapment syndrome at the elbow. Journal of hand surgery 1995; 20: 638-648 PubMed PMID: 8543871.

3 Osborne G. Compression neuritis of the ulnar nerve at the elbow. The Hand 1970; 2: 10 - 13 PubMed PMID: 4328789

4 Chan RC, Paine KW, Varughese G. Ulnar neuropathy at the elbow: comparison of simple decompression and anterior transposition. Neurosurgery 1980; 7: 545 - 550 PubMed PMID: 7207750
5 Foster RJ, Edshage S. Factors related to the outcome of surgically managed compressive ulnar neuropathy at the elbow level. J Hand Surg Am 1981; 6: 181 - 192 PubMed PMID: 7229295

6 Mackinnon SE, Novak CB, Myckatyn TM et al. Results of reinnervation of the biceps and brachialis muscles with a double fascicular transfer for elbow flexion. J Hand Surg Am 2005; 30: 978-985 PubMed PMID: 16182054

7 Ogata K, Manske PR, Lesker PA. The effect of surgical dissection on regional blood flow to the ulnar nerve in the cubital tunnel. Clinical orthopaedics and related research 1985; 193: 195-198 PubMed PMID: 3971623

8 Ogata K, Shimon S, Owen J et al. Effects of compression and devascularisation on ulnar nerve function. A quantitative study of regional blood flow and nerve conduction in monkeys. Journal of hand surgery 1991; 16: 104 -108 PubMed PMID: 2007800

9 Sugawara M. Experimental and clinical studies of the vascularized anterior transposition of the ulnar nerve for cubital tunnel syndrome. Nihon Seikeigeka Gakkai zasshi 1988; 62: 755-766 PubMed PMID: 3235894

10 Dai Z, Liu Y, Liu R. Anatomical changes and dynamic analysis after anterior submuscular transposition in treating cubital tunnel syndrome. Zhongguo xiu fu chong jian wai ke za zhi = Zhongguo xiufu chongjian waike zazhi $=$ Chinese journal of reparative and reconstructive surgery 2004; 18: 254-256 PubMed PMID: 15323433

11 Bodner G, Buchberger W, Schocke $M$ et al. Radial nerve palsy associated with humeral shaft fracture: evaluation with US-initial experience. Radiology 2001; 219: 811 -816 PubMed PMID: 11376275

12 Gassner EM, Schocke M, Peer S et al. Persistent median artery in the carpal tunnel: color Doppler ultrasonographic findings. Journal of ultrasound in medicine: official journal of the American Institute of Ultrasound in Medicine 2002; 21: 455 -461 PubMed PMID: 11934102

13 Peer S, Kovacs P, Harpf C et al. High-resolution sonography of lower extremity peripheral nerves: anatomic correlation and spectrum of disease. Journal of ultrasound in medicine: official journal of the American Institute of Ultrasound in Medicine 2002; 21: 315-322 PubMed PMID: 11883543

$14 \mathrm{Kopf} H$, Mostbeck GH, Loizides A et al. Ultrasound-guided interventions at peripheral nerves: diagnostic and therapeutic indications. Ultraschall in der Medizin 2011; 32: 440 -456; quiz 57-9. PubMed PMID: 21986925

15 Kopf H, Loizides A, Mostbeck GH et al. Diagnostic sonography of peripheral nerves: indications, examination techniques and pathological findings. Ultraschall in der Medizin 2011; 32: 242-263; quiz 64-6. PubMed PMID: 21667406

16 Mondelli M, Filippou G, Aretini A et al. Ultrasonography before and after surgery in carpal tunnel syndrome and relationship with clinical and electrophysiological findings. A new outcome predictor? Scandinavian journal of rheumatology 2008; 37: 219-224 PubMed PMID: 18465458

17 Mondelli M, Ginanneschi F, Rossi A. Evidence of improvement in distal conduction of ulnar nerve sensory fibers after carpal tunnel release. Neurosurgery 2009; 65: 696-700; discussion 1. PubMed PMID: 19834374

18 Assmus H, Antoniadis G, Bischoff C et al. Cubital tunnel syndrome - a review and management guidelines. Central European neurosurgery 2011; 72: 90-98 PubMed PMID: 21547883 